\title{
Pulmonary Embolus; Can Be Still Missed Easily!
}

\author{
Pulmoner Emboli: Yine de Kolaylikla Atlanabilir!
}

\author{
Betul Gulalp ${ }^{1}$, Tufan Akin Giray ${ }^{1}$, Nazan Sen ${ }^{2}$, Mehmet Nur Altinors ${ }^{1}$ \\ ${ }^{1}$ Department Of Emergency Medicine, School Of Medicine, Baskent University, Turkey. \\ ${ }^{2}$ Department Of Chest Diseases, School Of Medicine, Baskent University, Turkey.
}

\begin{abstract}
Introduction: Pleuritic pain can be misconstrued as renal colic.

Case: 32 years old female complained about her flank pain with changeable character for last three days. She had started to get oral treatment as renal colic in another hospital. The vitals were; temperature $36.8^{\circ} \mathrm{C}$, pulse $92 / \mathrm{min}$, respiration rate $22 / \mathrm{min}$, blood pressure $130 / 80 \mathrm{~mm} / \mathrm{Hg}$. Physical examination and bedside ultrasonography were unremarkable. The sinuses were not identified on chest $\mathrm{x}$-ray. $\mathrm{WBC}$ was $13.40 \mathrm{~K} / \mathrm{mm} 3$. The biochemistry tests were normal. D-dimer was $98 \mathrm{ug} / \mathrm{L}(50-228 \mathrm{ug} / \mathrm{L})$. There were bilateral multiple periferic tromboembolus on computerised tomography pulmonary angiography. Bilateral distal extremity venose system colorful Doppler were normal. Right heart cavities and all cardiac functions were normal. There was not an indication of trombolitic administration and the patient was admitted to intensive care with anticoagulation treatment.

Conclusion: If there were thrombosis risc factors, they should be evaluated in differential diagnose of pulmonary embolus. Evaluation of history about dyspnea could be the clue. Inexplicable dyspnea was the indication for advanced investigation methods. As symptoms were nonspesific, appropriate management can identify pulmonary embolus without any consultation in a short time, merely.
\end{abstract}

Key words: Pulmonary Embolus

\section{ÖZET}

Giriş: Plöritik ağrı renal kolik ile karıştırılabilir.

Olgu: 32 yaşında kadın üç gündür süren değişken karakterli yan ağrısı şikayetiyle başvurdu. Bir başka hastanede renal kolik için oral tedavi başlanmıştı. Vital bulgular; Ateş $36.8^{\circ} \mathrm{C}, \mathrm{Nb} 92 / \mathrm{dk}$, solunum sayısı $22 / \mathrm{dk}$, TA $130 / 80 \mathrm{~mm} / \mathrm{Hg}$ idi. Fizik bakı ve hastabaşı ultrasonografide herhangibir bulgu yoktu. Akciğer düz filminde sinüsler ayırd edilemiyordu. WBC 13.40 K/mm3 idi. Biyokimyasal testler normaldi. D-dimer 98 ug/L (50-228 ug/L) idi. Komputerize tomografi pulmoner anjiografide iki taraflı çoklu periferik tromboemboli mevcuttu. İki taraflı distal ekstremite venöz sistem renkli Doppler normaldi. Sağ kalp boşlukları ve tüm kardiyak fonksiyonlar normaldi. Trombolitik endikasyonu olmayan hasta antikoagülasyon tedavi ile yoğun bakıma yatırıldı.

Sonuç: Trombozis risk faktörleri eğer varsa değerlendirilmelidir. Öyküde dispnenin değerlendirilmesi ipucu olabilir. Nedeni açıklanamayan dispne ileri araştırma yöntemleri için bir gerekliliktir. Semptomlar belirgin olmadığı için sadece doğru hasta yönetimi ile pulmoner emboli herhangibir konsultasyon istenmeden kısa sürede belirlenebilir.

Anahtar Kelimeler: Pulmoner Emboli 


\section{INTRODUCTION}

Pulmonary embolus has a serious high rate of morbidity and mortality ${ }^{(1-9)}$. The risk factors in thrombosis are valuable to suspect about this disease occuring with probably predispotional reasons of hypercoagulation, venous stasis and venous injury ${ }^{(1)}$. Anatomic obstruction and neurohumoral effects are the pathophysiologic basic mechanisms explained as the reasons of increase in pulmonary arterial pressure ${ }^{(1)}$. Symptoms and findings are not diagnostical and imitate many other diseases ${ }^{(1,5)}$.

\section{CASE PRESENTATION}

32 years old female patient was presented with an complaint due to only upper flank pain for three days. She mentioned a similar pain experienced last year without consulted by a physician. She was examined in another hospital and started to treat as renal colic the day before. When she asked about, the patient explained the accompaniment of slight dysnea. Additionally, there was a regular usage of oral contraseptives in her history. The temperature was $36.8^{\circ} \mathrm{C}$, blood pressure was $130 / 80 \mathrm{~mm} / \mathrm{Hg}$, heart rate was $92 \mathrm{pulse} / \mathrm{min}$, respiratory rate was $22 / \mathrm{min}$, pulse-oximetry was 98 . Complete physical examinations were unremarkable. $\mathrm{PH} 7.47, \mathrm{pCO} 232 \mathrm{mmHg}$, pO2 $147 \mathrm{mmHg}, \mathrm{HCO} 323.3 \mathrm{mEq} / \mathrm{L}, \mathrm{Sa} 0299$ were measured on arterial blood gase analysis. It was measured during oxygen therapy starting with suspicion of pulmonary embolus as 2-3 L/min. WBC was $13.40 \mathrm{~K} / \mathrm{mm} 3$. Other complete blood counts values and $\mathrm{Na}, \mathrm{K}, \mathrm{Cl}, \mathrm{BUN}, \mathrm{Cr}$, glucose, alanine aminotransaminase, aspartate aminotransaminase, direct and indirect bilirubin were in normal ranges. Urine sample was normal. There was right bundle-branch block on EKG. Chest radiography revealed suspected Hampton sign on the left side (Figure 1). Bedside ultrasonography was nonspesifically. Emergent computed tomographic pulmonary angiography showed bilateral multiple peripheral pulmonary embolus (Figure 2). Doppler venous ultrasonography of bilateral distal lower extremities were normal. Echocardiography revealed normal findings without dilatation and dysfunction of right ventricle, therefore there was not an indication for thrombolytic therapy. Treatment included anticoagulation therapy with heparin and warfarin in emergency department. The patients were admitted to the intensive care. She had sepsis on fourth day and was discharged on the 17th day of admission with warfarin sodium oral treatment.

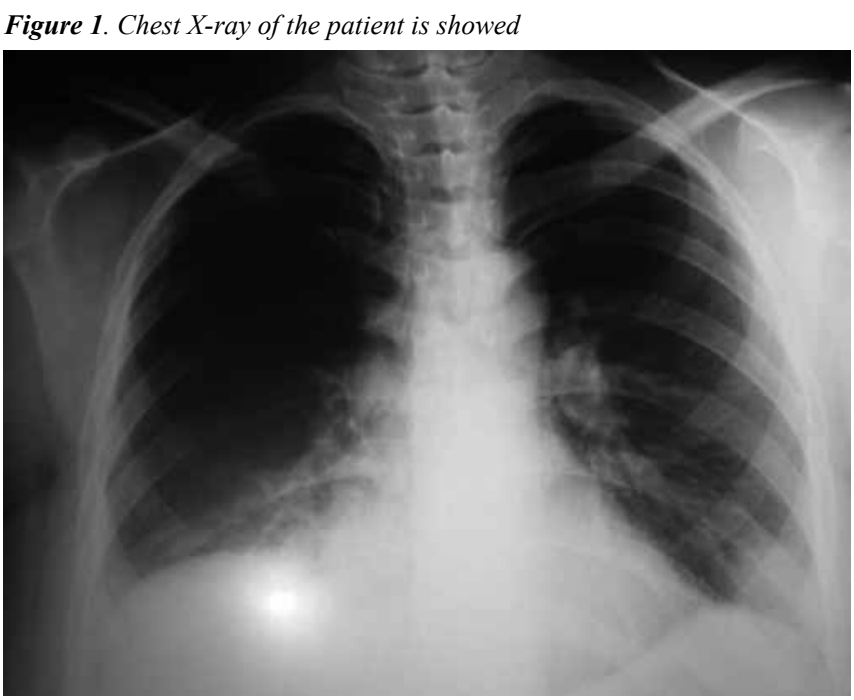

Figure 2. CTPA is demonsrated of the patient.

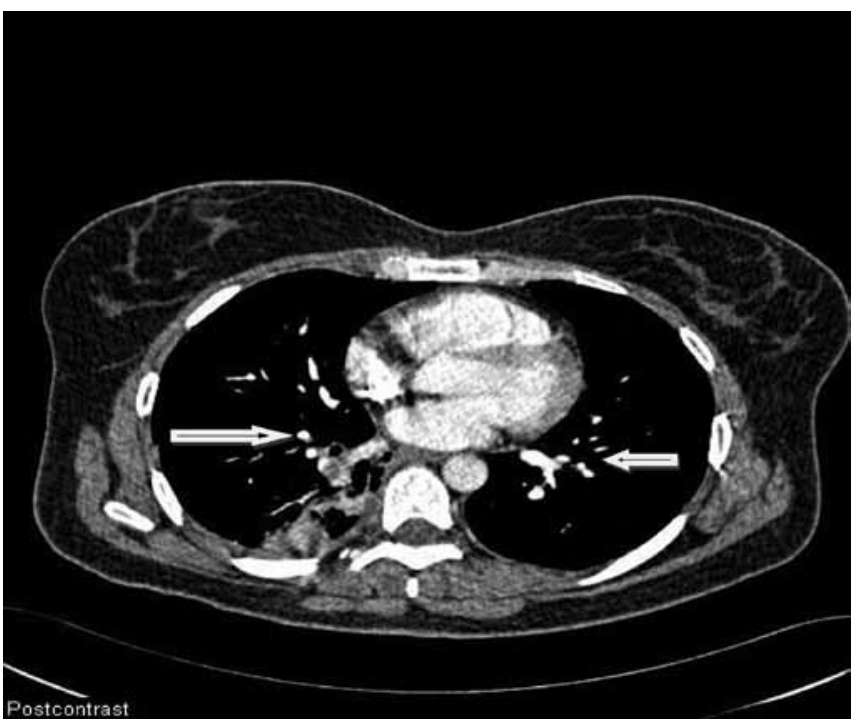

\section{DISCUSSION}

Every misdiagnosed pulmonary embolus patient was a probability for a mortal result. Whenever evaluated complaint of these patients meticulously, dyspnea could be ascertained almost in every patient ${ }^{(1,5)}$. Dyspnea, pleuritic pain, apprehension, cough, hemoptysis, sweating, nonpleuritic chest pain, syncope were the most symptoms ${ }^{(1)}$. Tachypnea, tachycardia, leucocytosis, hipoxi, ralles, fever, cyanosis, lower extremity edema can be associated ${ }^{(1)}$. However these were not emanate in $100 \%$ of patients. The dyspneic patient with undefined differential diagnose should be explored for pulmonary embolus ${ }^{(5)}$. The patient mentioned pain on the upper flank with a changeable character as renal colic, however she had dyspnea during her pain. Pleuritic pain in peripheral pulmonary embolus could mimic renal colic. In addition usage oral contraceptives composed the risky groups in females (1). However, thrombosis risk factor was not always necessary as there were not identified a risk factor in $15-24 \%$ pulmonary embolus patients ${ }^{(9)}$. D-dimer was a fibrin product in blood found after fibrin formation ${ }^{(9)}$. Measurement of D-dimer was reported with latex agglutination test and it was more sensitive enzymelinked immunosorbent assay (ELISA) ${ }^{(9)}$. D-dimer was negative with latex agglutination test as the half-life of D-dimer is lower than eight hours with a low sensivity ${ }^{(9)}$. The commencement 
of the complaints was three days before admission. When there was not a recurren embolus, normal value of D-dimer could be apparent . The nonspesific findings on chest $\mathrm{x}$-ray were mentioned in literature ${ }^{(2,3)}$. These could be oligemia (Westermark sign), vasculer redistribution, pleural-based opacity (Hampton sign), atelectasis (Fleischner lines), pleural effusion and elevated diaphragm ${ }^{(3)}$. Arterial blood gase was useful to demonstrate the alveolar-arterial PO2 gradient as increased gradient or hypocapnia in $98 \%$ of patients with PE showed by Cvitanic and et al ${ }^{(4)}$. Electrocardiogram findings could be normal in $46 \%$ patients or include incomplete or complete RBBB with nonspesific ST-segment, T-wave changes ${ }^{(5)}$. Mansencal and et al showed $58 \%$ of the patients had the diagnosis of thromboembolism with venous ultrasonography ${ }^{(6)}$. Pulmonary angiography was an invasive management, although being still the golden way to diagnose (7). Additionally, lung ventilation-perfusion scintigraphy was remained the most useful non-invasive method ${ }^{(7)}$. However both of them could identify only pulmonary embolus except other probable diagnosis in the emergency department ${ }^{(7)}$. Computerized tomography angiography was a diagnostic alternative and commonly used in differential diagnosis of pulmonary embolus within other cardiopulmonary diseases, albeit contrendicated in patients with renal insufficiency or contrast allergy ${ }^{(7)}$. In addition, radiation was the disadvantage as there should be a clinical indication for this management ${ }^{(8)}$. Some reports offered the evaluation of patients for both pulmonary embolus and deep venous trombus with the same contrast injection ${ }^{(7)}$. Magnetic resonance was another diagnostic tool, however it was slow and not costeffective ${ }^{(7)}$. If there was a patient with serious suspicion, computerised tomography pulmonary angiography was the common way to diagnose pulmonary embolus reported with a $88 \%$ sensitivity and $94 \%$ specifity ${ }^{(7)}$.

\section{CONCLUSION}

Pulse-oxymetry, EKG, D-Dimer, chest x-ray, blood gas, A-a gradient were supportive tests, although these were not diagnostical [9]. Symptoms and findings of pulmonary embolus could imitated many other diseases. The diagnose was directly related in the careful evaluation of patient besides the suspicion about pulmonary embolus.

\section{REFERENCES}

1. Stein PD. Acute pulmonary embolism. Dis Mon 1994;40:467-523.

2. Zubairi AB, Husain SJ, Irfan M, Fatima K, Zubairi MA, Islam M. Chest radiographs in acute pulmonary embolism. J Ayub Med Coll Abbottabad 2007;19:29-31.

3. Worsley DF, Alavi A, Aronchick JM: Chest radiograph findings in patients with acute pulmonary embolism: Observatios from the PIOPED Study. Radiology 1993;189:133-136.

4. Cvitanic 0, Marino PL: Improved use of arterial blood gas analysis in suspected pulmonary embolism. Chest 1989;95:48-51.

5. Stein pd, Henry JW: Clinical characteristics of patients with acute pulmonary embolism stratified according to their presenting syndromes. Chest 1996;109:78-81.

6. Mansencal NM, Vieillard-Baron A, Beauchet A and et al: Triage patients with suspected pulmonary embolism in the emergency department using a portable ultrasound device. Echocar 2008;25:451-456.

7. Wolfe TM, Hartsell SC: Pulmonary embolism: Making sense of the diagnostic evaluation. Ann Emerg Med 2001;37:504-514.

8. Runza G, La Grutta L, Alaimo V and et al. Comprehensive cardiovascular ECG-gated MDCT as a standard diagnostic tool in patients with acute chest pain. Eur J Radio 2007;64:41-47.

9. Weiner SG, Burstein JL. Nonspesific tests for pulmonary embolism. Emerg Med Cli Nor Am 2001;19:943-954. 